\title{
Self-care in individuals with chronic kidney disease on hemodialysis
}

\author{
Autocuidado en personas con enfermedad renal crónica en hemodiálisis
}

Autocuidado em pessoas com doença renal crônica em hemodiálise

\author{
Mariela Beatriz Andrade Santana ${ }^{\mathrm{a}}$ \\ Denise Maria Guerreiro Vieira da Silva ${ }^{b}$ \\ Maria Elena Echevarría-Guanilo ${ }^{b}$ \\ Soraia Geraldo Rozza Lopes ${ }^{c}$ \\ Priscila Juceli Romanoski ${ }^{b}$ \\ Julia Estela Willrich Böell ${ }^{b}$
}

How to cite this article:

Santana MBA, Silva DMGV, Echevaría-

-Guanilo ME, Lopes SGR, Romanoski PJ,

Böell JEW. Self-care in individuals with

chronic kidney disease on hemodialysis.

Rev Gaúcha Enferm. 2020;41:e20190220.

doi: https://doi.org/10.1590/1983-

1447.2020 .20190220 autonomous Researcher. Punta Arenas, Región de Magallanes y Antártica Chilena, Chile.

b Universidade Federal de Santa Catarina (UFSC). Programa de Pós-Graduação em Enfermagem. Florianópolis, Santa Catarina, Brasil.

Fundação Universidade Federal do Mato Grosso do Sul (UFMS), Programa de Pós-Graduação em Enfermagem. Coxim, Mato Grosso do Sul, Brasil.

\section{ABSTRACT}

Objective: To understand how self-care is carried out by people with chronic kidney disease on hemodialysis.

Method: A qualitative approach was used. Data was collected through semi-structured interviews in 12 individuals on hemodialysis in Chile between September and December 2018. Dorothea Orem's self-care theory was used for directed content analysis.

Results: Three categories emerged: self-care requirements, self-care deficit, and education and information management for selfcare. People were aware of the importance of carrying out their self-care. They also stated not to carry out the care actions rigorously enough showing some limitations. Finally, people's knowledge about their condition was usually acquired from the Internet and from their own experience rather than through consultations with a health team.

Considerations: People are conscious about their role in their health in a flexible way. The health team should know how to recognize conditions interfering in people's self-care and help to overcome them.

Keywords: Kidney dialysis. Kidney insufficiency, chronic. Chronic disease. Self-care.

\section{RESUMEN}

Objetivo: Comprender cómo se realiza el autocuidado en personas con enfermedad renal crónica en tratamiento de hemodiálisis.

Método: Abordaje cualitativo con entrevistas semi-estructuradas con 12 personas en tratamiento de hemodiálisis en Chile entre los meses de septiembre y diciembre de 2018. Se empleó el análisis de contenido dirigido por la teoría de autocuidado de Dorothea Orem. Resultados: Surgieron tres categorías: requisitos de autocuidado, déficit de autocuidado, y educación y manejo de información para el autocuidado. Las personas conocían la importancia de ejecutar su autocuidado. Sin embargo, no realizaban los cuidados con rigurosidad. Adquirían los conocimientos por Internet y a partir de la propia experiencia, no recurriendo al equipo de salud ante dudas. Conclusiones: Las personas demostraron ser conscientes de su rol en preservar su salud, pero de forma flexible. El equipo de salud debe reconocer los aspectos que interfieren en el autocuidado y ayudar a las personas a superarlos.

Palabras clave: Diálisis renal. Insuficiencia renal crónica. Enfermedad crónica. Autocuidado.

\section{RESUMO}

Objetivo: Compreender como 0 autocuidado é realizado por pessoas com doença renal crônica em hemodiálise.

Método: Abordagem qualitativa com entrevistas semiestruturadas com 12 pessoas que realizavam hemodiálise no Chile entre os meses de setembro e dezembro de 2018. A análise de conteúdo foi conduzida pela teoria do autocuidado de Dorothea Orem.

Resultados: Surgiram três categorias: requisitos de autocuidado, déficit de autocuidado e educação e manejo de informação para 0 autocuidado. As pessoas reconheceram a importância de realizar seu autocuidado. No entanto, referiram não realizar o cuidado com o rigor que deveriam. Os conhecimentos que possuíam foram adquiridos na internet ou de sua própria experiência, sem recorrer à equipe de saúde.

Conclusões: As pessoas são conscientes de seu papel na manutenção de sua saúde, mas de maneira flexível. A equipe de saúde deve saber reconhecer os aspectos que interferem no autocuidado e ajudar as pessoas a superá-los.

Palavras-chave: Diálise renal. Insuficiência renal crônica. Doença crônica. Autocuidado. 


\section{口INTRODUCTION}

Maintaining people's participation in the care required by their health condition is fundamental in any pathology, especially if it is a chronic one. Many people live without the tools which allow for their empowerment in their care and for them to adapt to the changes they need to implement in their lives to improve their health. Such is the case of those who suffer from Chronic Kidney Disease (CKD) and who follow a hemodialysis (HD) treatment since, for being mostly performed three times a week, it generates many other care needs related to the maintenance of the desired compensation. These care actions involve changes in the eating habits, liquid intake, and adherence to HD, among others ${ }^{(1-2)}$.

These necessary changes become even harder to maintain in time, especially if the person is not aware of the importance they have in their life, apart from not having the tools needed to approach the care actions. In addition to this, there is evidence that people show the desire to improve problem resolution to attain the objectives proposed for their health ${ }^{(3)}$.

The aforementioned emphasizes the importance of implementing self-care in people so that they assume full responsibility of their own care actions by actively participating in maintaining their health. The importance is highlighted of studying the phenomenon of living with CKD on HD treatment, especially from a qualitative perspective, exploring people's experiences and their perception of the process they are going through and of how they care for themselves.

The objective of the present study was to understand how self-care is performed in people with CKD on HD, in order to understand the difficulties they face in their daily care measures, their actions and their deficits.

\section{METHOD}

The present study had a qualitative approach, of the descriptive and exploratory type. Part of the theory by Dorothea Orem was chosen as a theoretical referential, for analysis orientation, and for discussion of the data of the present study. The author sets out the theory of Self-Care Deficit, defining the concept of self-care as "practicing the activities that mature people, or those in the process of maturation, start and carry out in certain periods of time, on their own and with the interest of maintaining a lively and healthy functionality, apart from continuing their personal development and well-being by satisfying requirements for the functional and developmental regulations ${ }^{\prime \prime(4)}$.
The individuals were selected through intentional sampling, composing the sample with 12 people in an HD unit of a hospital in the South of Chile, between the months of September and December 2018. Due to the short data collection period, the number of the sample was established with the objective to comply with the different characteristics of the individuals on $\mathrm{HD}$ and in a way that, at the same time, could be approachable, thus deepening on the individual experiences. To this end, people of different ages, of both genders, with different times on HD treatment, and even in different care shifts were included.

The HD unit had a total of approximately 100 individuals on treatment as to the research date, with a three shift system and a health team made up by 6 women nurses and 6 nursing technicians, where the care provided is based on the connection and supervision of HD, apart from assessing the health condition of the people and responding to spontaneous consultations, for which they reinforce knowledge or refer to a physician if necessary.

To start data collection, an approach period was conducted in the unit where the people were on HD treatment, so that they could meet the researcher and know the details of the study; this created a sense of acknowledgment which favoured the initial dialog. Subsequently, the invitation was made personally to those who showed willingness to express their experiences and who, by the health team's suggestion, had higher availability to talk. Finally, to finish the participation of the person, a new contact was made together with a telephone invitation, where further details on the purpose of the study were given. Following the acceptance to participate, the date, time and place of the interview were scheduled.

The semistructured interviews were carried out according to availability and preference, in each person's home, where the following triggering statement was set forth: "Talk to me about your experience with CKD and HD, and about how you perform your self-care actions", with the aim that the answer was free and true to the life experience. In addition to this, other questions were asked during the interview to explore the theme of self-care. All the interviews were conducted by the lead author.

The interview was conducted with the signing of the informed consents for participation in the study, also authorizing digital recording and note-taking by the researcher. In addition $m$ a data emptying template was used for the collection of general background.

Once the interviews were transcribed, they were analysed by means of directed content $t^{(5)}$. The analysis process was performed with the coding of the interviews, with 
Dorothea Orem's self-care theory as a reference, seeking to identify the demands, actions, and education for self-care, as well as the aspects which can exert an influence on them. After this process, the codes were organized by similitude and by answering to the research objectives. With this grouping by similitude as a starting point, the categories and subcategories were created.

The participating individuals were selected according to the inclusion criteria: being over 18 years old, with more than 6 months on HD treatment, and time-space oriented. This last criterion was assessed subjectively according to the first approaches to the people in the HD unit, and also according to what was pointed out by the health staff involved in the care provided. With respect to the exclusion criteria, it was established that the individuals should not suffer from very debilitating associated pathologies, like cancer or mental illnesses; this was because the desire was to inquire about CKD and $\mathrm{HD}$, avoiding in this way addressing other problems that can also generate stress in people.

In this research study, ethical aspects were considered to safeguard the integrity of the participating individuals. The application principles of informed consent, scientific value, favourable risk-benefit relation, validity, respect towards the participants, and independent project review were followed ${ }^{(6)}$. The individual's integrity was safeguarded during the whole research process: before, during, and after. To this end, confidentiality and respect were preserved, and the data were handled adequately, respecting the times and reports expressed, apart from signing the pertinent informed consents. The Ethics Committee of the University of Magallanes approved the study through Certificate No. 044/CEC/2018.

\section{RESULTS}

People with CKD on HD treatment recognized the importance of maintaining the care measures in their daily lives. The following categories reflecting the experience in relation to self-care resulted from the process: Self-care requirements, Self-care deficit, and Education and handling on the information for self-care, all represented in Chart 1

\section{CATEGORY 1: SELF-CARE REQUIREMENTS}

The individuals acknowledged that they should implement care actions to maintain their health. The self-care demands rose from the very beginning of the treatment; some were identified by the people themselves, but the

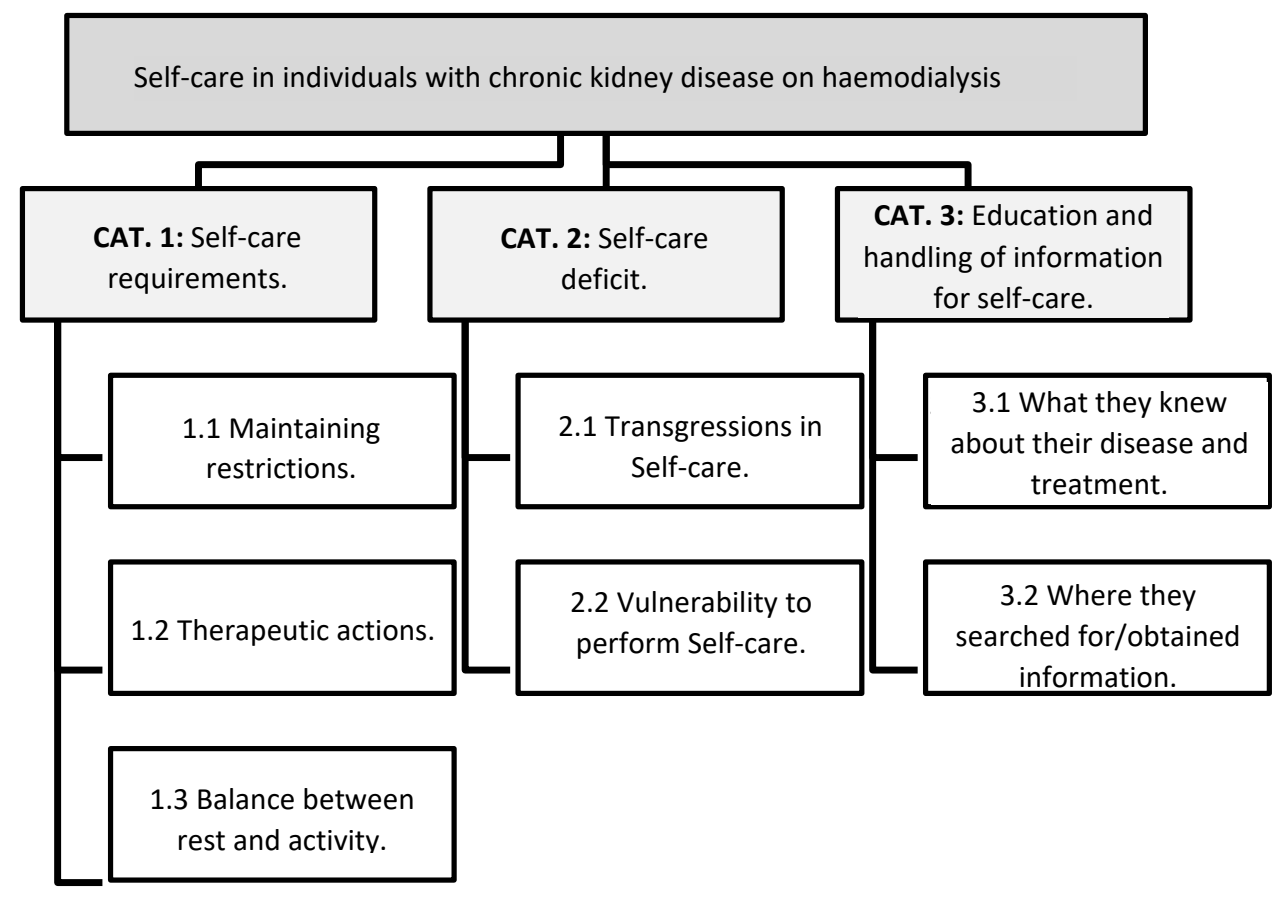

Chart 1 - Self-care in people with Chronic Kidney Disease on Hemodialysis

Source: The authors. 
majority were indicated by the health professionals involved in the care provided.

\section{Maintaining restrictions}

The main self-care demand which people recognized was related to performing care actions based on important restrictions for which they had changed habits of their daily lives. These were mainly based on controlling nutrition and liquids intake. The majority stated that they could eat anything, but with restrictions. For some, following the diet had not been a difficult process; for others, it was one of the hardest aspects to maintain in their care actions.

According to the guidelines provided by the staff, maintaining the diet generated tiredness in the individuals, who made an effort to keep it in their daily routine:

[...] as I told you, it's hard, eating is hard, but you try to do it all you can. (P6).

Some people stated they could eat anything, even the foods restricted by the health team. They considered it was not necessary to limit the type of food eaten, but to be careful in its frequency and quantity:

[...] / can eat anything, anything, but not in excess [...] things like that, but forme they are not big problems (P3).

[...] I've always said: you can eat anything, but as long as you are moderate, because you're not going to eat one kilogram of potatoes or things like that, but I thinkyou can eat everything, but as long as you do so orderly. (P9)

With regards to the intake of liquids, several people recognized it as an important requirement of their self-care, although they expressed difficulties to put it into practice:

The physician has told me it's a lot of water, he blames the liquid and the liquid, but one day I told the doctor: 'Doctor, I don't drink so much liquid'. I took the glass where I drink coffee and the cup where I drink water, a little-little glass in which I drink coffee, I took it and told him, "it's this", I drink four to six a day. (P2)

\section{Therapeutic actions}

The people needed to follow the therapeutic indications provided by the health professionals; among those indications, going to dialysis was considered as a responsibility they could not escape from, they considered it as "sacred", essential for their well-being. To this end, they adjusted their routines to going to $H D$, as can be seen below:

If I don't make it to dialysis I'm going to die, if I wanted to live I had to take care of my kidneys [...] it's sacred forme. (P12)

I can say to myself, I hate the damn dialysis, it's bullshit and all you want, but I'm never going to walk out on it, I'm never going to walk out on my dialysis [...]. (P9)

Medication use was considered as indispensable for maintaining their health, for which they took special care to take them according to the indication:

[...] / have them very clear, it's only me that handles that, there are other people who need someone else to handle the medications. (P10)

[...] I have my pill case, then I put the medications for the day there, I put it there, I already have all my times for what I have to take in the morning, noon, and night, so there's no problem. (P11)

The participants considered the consultation with a physician as relevant to carry out their care actions. For this reason, they stayed in contact with him to get answers to their daily needs, either to report how they got up or to extend a pending prescription.

[...] I consult him anything, doctor $X$ treats me, but he comes to where l am and asks me, "how are you doing? And then I ask him." (P5)

[...] if I need the prescription or anything, the doctor writes it right away, so in that sense welead the matter well. (P10)

In addition, they also showed themselves active in their care actions, demanding attention from the physician when faced with doubts which might arise in their care actions:

I also think, they can give me this, they can give me that, for example, he had withdrawn insulin once and they started to give me pills, a covering woman physician who had never seen me. I set out to talk to her and told her, "look, doctor, I used this and that of insulin, they gave the pill and nothing happens, I want go back to insulin." (P7) [...] I approach the secretary and tell her, "listen, can you print my exams?", I put them away, I have them, I look at them, I see what went wrong and then I go to the doctor, I tell him, "listen, you know this went wrong, I keep control of all my exams. (P9) 


\section{Balance between rest and activity}

The individuals claimed to feel very tired, especially after HD. In view of this, some people stated the importance of being able to rest to continue with their routine, whereas others needed to rest and did not feel like doing anything else during the day:

[...] now the only thing I want to do is to keep indoors, sleep, rest, I don't feel like anything..." (P2)

[...] you get your body used to your own rhythm, I go out, rest for an hour, recover well and go out to work. (P12)

In addition, people stated the need to continue doing physical activity to maintain their health:

Exercise, walking a lot, jogging, doing exercise here in the house and that is what has strengthened my body. My muscles went back to normal, as it was before, but I've almost made it, although I was skin and bones, I didn't have any muscles in my body and I've made it little by little. (P4)

[... I still go the days I don't have dialysis, I go downtown to walk, wander a little, not stay at home, I try, although I'm not well... I go out for a stroll. (P10)

\section{Q CATEGORY 2: SELF-CARE DEFICIT}

The individuals recognized they had self-care deficits. Even those who said they did all of what was indicated to them, they contradicted themselves at some other time, indicating they did not do so or that they could improve. Some people did enough to survive and made adaptations they considered adequate to their life and health condition.

\section{Transgressions in Self-care}

Carrying out care actions in compliance with the restrictions indicated by the health team was a daily challenge for the people. Transgressions occurred when they did not perform the self-care actions deliberately, since there were some elements contributing to that. As regards liquids intake, they stated they drank more than they should, prioritizing water intake over nutrition, which can be appreciated below:

I drink water all day, sometimes I stop eating and prefer to drink two litres of water [...] then I go idiotic because I can't drink water, ''ve made it with 900 grams, 800 grams, but I go idiotic all day (laughs). (P12)
The individuals showed themselves quite resistant to changes in their food consumption, which should be restricted, to the point of asserting they preferred to die rather than eating what they did not like. They tried to transgress the diet the day before HD so that they could stabilize during the treatment:

[...] I know very well that when I eat something, for example, and have dialysis tomorrow, in the afternoon I can eat an avocado pear and I polish one off sinlessly, I know that tomorrow they're going to take it out of me from the dialysis, then I treat myself with the avocado pear. (P1)

Doctor $X$ is always arguing with me and tells me that I don't have to drink soup but, if I like it, darn if I'm going to die, I prefer to die eating what I like, what's the point in having such a big plate, a little [...] the casserole, l eat it Saturday night at the most, it's my last dialysis on Saturday, or Sunday at lunchtime, so I have to recover Sunday afternoon and Monday, because I go until Tuesday. (P7)

Another difficulty identified was the limitation when practicing physical activity: many of them saw themselves limited by the tiredness caused by CKD and HD, whereas others stated difficulty due to the city weather, as can be appreciated below:

I'd like to walk more but all the same l limit myself because of the weather, it's hard to go out, wind, cold. (P3)

The fact is I can't practice sports any more [...] a little effort and I get tired like that, my bones start to ache, my muscles, everything hurts when I make a little effort. (P6) The thing is that I can't practice that much, at first I couldn't do anything [...] / couldn't do even one situp because the catheter was going to come out, now I practice a little more, but I have to be careful with my fistula, but I do a little more all the same, but clearly my body isn't the same, I get tired like that and my heart starts tearing me to pieces. (P9)

Despite the fact that most of the individuals stated that HD was essential to maintain their health and not to have any complications, some walked out on the sessions, only going when they felt the need to or when they were able do so, due to family responsibilities or to their life routines. They also expressed doubts about going to HD frequently:

Sometimes there's no one to take care of my children. The days I have to go to dialysis and I'm alone and the children 
go to school [...]. Then I can't make it and leave them on their own for their test, you have to be with them. (P4)

[... .] sure you don't feel like going, you say "next year I don't go any more", but no, the day after it's gone, it's like a mental depression. (P6)

The use of medications referred to by most of the people was according to the medical indication; some forgot to take them, did not take them due to the collateral effects or because they believed they were fine after seeing the results of their exams. There also individuals who made use of medications without any medical prescription:

Taking the medicines, I forget, but I don't need them either, because with everything I eat I have calcium, with everything leat I have vitamins, suddenly it's not necessary to depend on the pills. (P8)

The health controls and/or the exams were not carried out at the established times, referring they were no longer necessary because they already went to HD frequently:

Doctor X, he's there and sees us day after day, he says that, if the person is fine, what's the point of going to the consultation ifl'm going to tell him the same. [...] There's no point in spending more hours than a person with more problems than me can spend, so I don't worry about that either, as I tell you the doctor is there and always. (P10)

[...] I'm a little lazy all the same, I don't take the calciums a lot, when the cramps start in my face I start with the calcium (laughs). (P12)

\section{Vulnerability to perform Self-care}

The people showed they made the effort to maintain their care actions, but they were affected by certain limitations which lead them to transgressions. An example was tiredness, manifested as one of the main limitations to perform their care actions, since it was difficult to maintain a correct execution after so much time in treatment:

The care actions are mostly to survive, but a time comes that you get tired. (P6)

As regards the use of medications, the individuals stated they did not feel at ease having to take so many drugs. For this reason, they chose another option which made them feel comfortable, either abandoning the treatment or replacing it by natural options:
[...] it's a burden on me having to take so many medicines, I can't stand it, I prefer to take naturalist medicines, naturals, they have for everything and that's it. (P8)

I didn't like it, I said I wasn't going to take it and I didn't take it anymore and l've felt better, but after years now he gave them to me again, but I don't always take them, it's that I don't like them. (P9)

Some people indicated information was missing at the beginning of the treatment, causing doubts in the indications provided by the health staff. Some were not conscious at the time of their first dialysis, where the family members were informed about the channels to follow. So people expressed doubts on the information provided:

[...] you always keep doubting if it's true or not, you always like to confirm it. (P6)

[...] he told me, "you go to dialysis and that's it" [...] I went to dialysis all on my own without knowing anything. (P12)

In some people, the presence of the venous catheter caused difficulties in performing the personal care actions, since the individuals said they had to clean themselves "part by part" in order to attain an adequate level of hygiene without neglecting the catheter.

Economic income was an aspect which limited the performance of the care actions, especially those regarding to nutrition. The need to integrate foods of a good nutritional quality hinders access to them for a certain group of people because they are generally very costly:

What's my lunch? When I go to dialysis, the nutritionist also scolded me by the way, what can I do about it, it's a piece of bread, but that's my lunch. (P7)

\section{CATEGORY 3: EDUCATION AND MANAGEMENT OF INFORMATION FOR SELF-CARE}

Most of the people knew how to perform their self-care actions, but they nevertheless had difficulties understanding what to do and how to do it, signalling the absence of clear and complete guidelines from the health professionals as the main gap. One of the most outstanding elements was the difficulty in relation to the professionals, who do not always understood the doubts and difficulties people were undergoing to perform their self-care actions. This perception was not related to all the professionals, the biggest difficulty was with the new ones. This lack of information at 
the beginning of the disease and of HD generated a lot of insecurity in them, made them suffer and to not follow the treatment adequately.

\section{What they knew about their disease and treatment}

From the beginning of their HD treatment, the individuals handled information but, nevertheless, they had many deficiencies which influenced on the performance of their self-care actions. Some people asserted they had all they needed to carry out their care actions but, on the other hand, there were those who still did not have crucial information to maintain their health.

Providing information at the beginning of the treatment defined the care actions people were to carry out, as well as the learning process they had undergone, not always under the supervision of the health team:

We can immediately try to get you an institution with a drug that helps to stop the harm to extend your time. But I was a pussyhead at that time, I didn't know, I had no clue of life, I had nowhere to fall upon, and I couldn't get the drug. (P1)

Experience was also a factor during which people had progressively learned about their care actions:

It's been 26 years that I've known myself, when I have any discomfort I say, it must be so long, with 26 years, that I could have retired here in the hospital (laughs) (P12)

\section{Where they searched for/obtained information}

Many times, the search for information was due to not feeling satisfied with the one provided in the unit by the health team, having to supplement it mainly through Internet. Likewise, there are people who stated having received education from the health staff:

He explained my disease to me, my doctor not so much, but the nurse I had, my nurse was special, I mean, because she was exclusive for $m e, X, X$ also explained many things when I had doubts. (P4)

The dialysis nurse explained to me, she more or less told me how dialysis was and then how to take care [...] the nutritionist, and the doctor too, so you go learning all that, knowing how things are" (P10)
Yes, Ilook, any symptom I see I search for it on the Internet, and go seeing. (P11)

In addition, they resorted to other sources of information, like congresses or the experience of other peers. Finally, the account is presented of a person who mentioned having received counselling from a physician on the Internet, which helped in decision making:

Well, in time you go listening what they say to the person next to you, I pick my ear up to listen and I don't know if it's bad or not, but l'm very nosy. (P7)

Year after year we have a Congress with doctors, true nephrologists [...] theylecture in other countries, it's because they're the best [... ] the day after they come, on Sunday we have a meeting with everything that's recorded. (P8) I started searching on the Internet and there's a woman doctor who's online [...] / consulted about the biopsy, what happened and the doctor told me not to do it. (P5)

\section{DISCUSSION}

In her Self-Care Theory, Dorothea Orem sets out the important role people who suffer from a disease must perform to carry out the care actions which will compensate their health condition ${ }^{(4)}$. This is limited in some cases where the beginning of the disease and treatment is often confusing, without having the required tools to carry out the care actions at that moment, which can even cause complications. The lack of previous readiness for the first dialysis sessions is an important factor to understand self-care. The illusive expectation is for people to start the care actions immediately, without any sound knowledge base, and that they succeed. In that respect, in a bibliographical review published in 2014, the importance is reflected of knowledge when facing a pathology, with a benefit associated to survival, avoiding complications which might warrant hospitalization in 17\% of the cases and which provides confidence to the person to face their disease ${ }^{(7)}$.

Various self-care requirements are present in people with $\mathrm{CKD}$ on $\mathrm{HD}$, requirements to which the individuals must answer to maintain their health; these requirements demand different levels of effort, since some people already had them incorporated into their habits and they only needed a slight change, and other requirements are extremely restrictive and force people to change their daily habits. The individuals are aware of the importance of carrying out the care actions to endure $C K D$ and $H D$, apart from maintaining their quality of 
life. This befits a study conducted in Brazil with 165 individuals, where it could be observed that they possess a good self-care ability, apart from a positive relation being present between self-care and quality of life related to health ${ }^{(8)}$.

Considering then that the self-care requirements are different for each person, it is the health team's responsibility to identify the individualities, working in a specialized care and adapting to their lifestyles so that, together with the individuals, they can manage to identify the self-care requirements and work on them. These facts are set out by Orem as those actions people must perform because they are necessary for the correct functioning of their own health ${ }^{(4)}$.

The health professionals must clearly understand that each person is unique and, therefore, so are their self-care requirements. The Nursing professionals are then the most trained individuals to understand and identify those aspects people must pay attention to in order to maintain their health and avoid complications ${ }^{(4)}$. Likewise, the individuals are able to identify on their own which the self-care requirements are and to define those they consider important to manage their HD and CKD treatment.

As regards the therapeutic self-care needs, the Chilean Nephrology Society states the importance of nutrition in patients with kidney disease, together with medical and dialysis management. Maintaining the electrolyte balance, an optimum weight between each dialysis session, and blood pressure in healthy ranges are important parameters in the care of people in treatment ${ }^{(9)}$.

In relation to the deficits of self-care, people are aware of how to perform it, as well as of the importance of good care actions to keep their disease compensated, but they transgress. There also daily difficulties which exert an influence on the self-care ability, making people present a selfcare deficit for not being able to respond effectively to their health needs. However, they are aware of the importance of performing self-care ${ }^{(10)}$.

People need to feel free to make their own decisions, although they might not be the adequate ones, such as eating some food they like or walking out on HD sessions, preferring to live like that, with the risk of decompensating. This is related to a research study conducted in Spain which, even if it uses a different methodology, does not differ from ours, since the majority state that the diet and liquid restriction limits them very much or a lot ${ }^{(11)}$. Not performing the care actions is an intermittent behaviour, similarly to a research study conducted in Madrid, where the results signal that there is lack of adherence to the diet and to the intake of liquids ${ }^{(12)}$.
Other derived difficulties are family responsibilities and the sensation of feeling good. Similar results are obtained in a study conducted in Peru, where people did not attend HD because they felt good, as well as for the lack of economic resources to go to the unit ${ }^{(13)}$.

Tiredness for maintaining the care actions is another characteristic present in people with CKD on HD, being one of the main causes for abandoning the treatment, together with the long time they must be alert to their health condition. Similar results are presented in other chronic pathologies, such as Diabetes Mellitus 2, where $58.8 \%$ does not adhere to the treatment due to forgetfulness and $29.9 \%$ for having to take many medications ${ }^{(14)}$.

Most of the people know what they have to do to carry out their care actions, as well as how to manage their complications, where the experience accrued during the disease process expands their knowledge. It is observed that people search for information when a new symptom arises, or when they have any doubt they consider important. The most consulted sources of information are the Internet, other peers' experience, congresses, and health professionals, but those they trust the most. This befits another study conducted with 411 individuals with a cancer diagnosis in Canada where $57.4 \%$ of the participants prefer the Internet as a source of information, followed by $32.6 \%$ with the involved health professionals ${ }^{(15)}$.

In view of this, Orem sets out the Nursing Systems theory, referred to as the practice by the Nursing professional to be able to intervene in the care actions people apply to themselves, so as to protect and regulate their self-care activities. Based on this point, the importance is highlighted of education to guarantee the correct performance of the care actions, both in and out the HD unit, considering the management of the information they have and search for in order to complement and improve the care provided in the HD unit ${ }^{(4)}$.

An empowerment of the health condition by most of the people with CKD on HD is observed. This must be taken into account because there are also some people who still cannot empower themselves; in view of this, Orem also offers an aspect which helps in this situation. The dependent care agent must be identified by the nurse, in case the person has difficulties to respond to the requirements needed to attain self-care. This agent will be the person who can make up for the person's deficit and, thus, comply with the care actions. The importance of the Nursing professional when timely identifying the dependent care agent is crucial, since the disease progress can lead into episodes where the person 
cannot perform effective self-care actions for not being in a good health condition. In view of this, the self-care agent can face this deficit and take care of the health condition ${ }^{(4)}$.

Finally, creating a bond with the person increases adherence to the therapeutic treatment, where the nurse must provide continuous feedback to foster self-care ${ }^{(16)}$. Providing education and the motivational incentive have proved to allow for a better management of the health condition and for an increase in self-management ${ }^{(17)}$.

\section{FINAL CONSIDERATIONS}

During their disease process, people stated the identification of the self-care requirements to be performed, making different changes in their lifestyles to respond to the care actions, some with more difficulties than others, but showing awareness of their role in maintaining their health.

Although people are responsible and aware of the importance of maintaining their self-care, some do not perform it with the same perseverance, generating certain flexibility in their care actions which, in a way, makes them feel with some control of their lives, such as occasionally "indulging" in their meals or walking out on an HD session a week to perform other activities.

The health team must know how to identify the aspects which interfere in people's daily self-care, since the quality of the care actions varies with time and according to the life context of the individuals in treatment. It is here that the professional must be alert to these difficulties, offering the necessary support so that self-care can be maintained. Apart from improving quality of life, this will provide more stability in CKD and will avoid complications.

When put into practice, Dorothea Orem's theory is an easily applicable guide, which serves as a reference in Nursing daily interventions. This can allow considering aspects related to the person under Nursing care, who are not always assessed in HD routine care. In this way, being able to improve people's well-being providing quality and humanized care, focused on the individual needs of the people. In turn, this will improve the effective care actions at home, which could reduce the health team's workload, since they have an active person in the self-management of effective self-care actions.

Among the limitations of the study, the results obtained were mostly of the descriptive type, which did not allow deepening in the understanding of the interferences for the correct performance of self-care in people with CKD on HD treatment and in which the personal components are which make a difference among them. This constitutes a starting point to continue conducting research studies which can deepen understanding in these areas which, undoubtedly, will manage to expand the knowledge of the lives of those who must live with this disease and treatment.

\section{REFERENCES}

1. Serra V, Serra RM, Viera GM. Las enfermedades crónicas no transmisibles: magnitud actual y tendencias futuras. Rev Finlay. 2018 Jun [citado 2019 mar 10];8(2):140-8. Disponible en: http://scielo.sld.cu/scielo. php?script=sci_arttext\&pid=\$2221-24342018000200008

2. Figueredo BN. Compañero de vida: enfermedad crónica: un estudio de caso. Index Enferm. 2014 Jun;23(1-2):46-50. doi: https://doi.org/10.4321/ S1132-12962014000100010

3. Silva RA, Melo GAA, Caetano JA, Lopes MVO, Butcher HK, Silva VM. Accuracy of nursing diagnosis "readiness for enhanced hope" in patients with chronic kidney disease. Rev Gaúcha Enferm. 2017 Mar;38(2):e65768. doi: https://doi. org/10.1590/1983-1447.2017.02.65768

4. Orem D. Nursing: concepts of practice. 6. ed. St. Louis: Mosby; 2001.

5. Hsieh HF, Shannon S. Three approaches to qualitative content analysis. Qual Health Res. 2005 Nov;15(9):1277-88. doi: https://doi.org/10.1177/ 1049732305276687

6. Emanuel E, Wendler D, Grady C. What makes clinical research ethical? JAMA, 2000 Sep [cited 2019 Mar 15];283(20):2701-11. Available from: https://www. dartmouth.edu/ cphs/docs/jama-article.pdf

7. Bonilla LFJ. Educación sanitaria al paciente con enfermedad renal crónica avanzada: ¿existe evidencia de su utilidad? Enferm Nefrol. 2014 Jun [citado 2019 mar 10];17(2): 120-31. Disponible en: http://scielo.isciii.es/scielo. php?script=sci_arttext\&pid=\$2254-28842014000200006

8. Bettoni LC, Ottaviani AC, Orlandi FS. Association between self-care and quality of life in chronic kidney disease patients. Rev Eletr Enf. 2017;19:a14. doi: https:// doi.org/10.5216/ree.v19.27442

9. Sociedad Chilena de Nefrología. Guía de nutrición para la hemodiálisis. Santiago: SCN; 2010 [citado 2019 mar 20]. Disponible en: https://www.nefro. $\mathrm{cl} / \mathrm{v} 2 /$ biblio/guias/36.pdf

10. Ruiz GE, Latorre LLI, Delgado RA, Crespo MR, Sánchez LJL. Adherencia al tratamiento farmacológico en pacientes en hemodiálisis. Enferm Nefrol. 2016 Jul-Set [citado 2019 mar 20];19(3):232-41. Disponible en: http://scielo.isciii. es/scielo.php?script=sci_arttext\&pid=\$2254-28842016000300005

11. Ahís TP, Peris AlC, Meneu OM, Pérez BCM, Bonilla CB, Panizo GN. Subjective impact of non-pharmacological strategies to improve quality of life and therapeutic compliance in hemodialysis patients. Enferm Nefrol. $2017 \mathrm{Mar}$ [cited 2019 Mar 20];20(1):22-27. Available from: http://scielo.isciii.es/scielo. php?script=sci_arttext\&pid=\$2254-28842017000100003

12. Heras MMT, Martínez RC. Conocimiento y percepción nutricional en diálisis: su influencia en la transgresión y adherencia: estudio inicial. Nutr Hosp. 2015 Mar;31(3):1366-75. doi: https://doi.org/10.3305/nh.2015.31.3.7942

13. Herrera-Añazco P, Palacios-Guillen M, Mezones-Holguin E, Hernández AV, Chipayo-Gonzales D. Baja adherencia al régimen de hemodiálisis en pacientes con enfermedad crónica renal en un hospital de referencia del Ministerio de Salud en Perú. An Fac Med. 2014 [citado 2019 mar 15];75(4):323-6. Disponible en: http://www.scielo.org.pe/scielo.php?script= sci_arttext\&pid=S1025-55832014000400005 
14. Maidana G, Lugo G, Vera Z, Acosta P, Morinigo M, Isasi D, et al. Factores que determinan la falta de adherencia de pacientes diabéticos a la terapia medicamentosa. Mem. Inst. Investig. Cienc. Salud. 2016; 14(1):70-77. Doc: http://scielo.iics.una.py/pdf/iics/v14n1/v14n1a11.pdf

15. Shea-Budgell MA, Kostaras X, Myhill KP, Hagen NA. Information needs and sources of information for patients during cancer follow-up. Curr Oncol. 2014 Ago;21(4):165-73. doi: https://doi.org/10.3747/c0.21.1932

16. Salimena AMO, Souza, MO, Melo MC, Simões C, Ferreira MR. 0 cotidiano da mulher em hemodiálise. Daily life of a woman undergoing hemodialysis. Rev Pesqui: Cuid Fundam. 2016 [citado 2019 mar 15];8(3):4636-4643. Disponível em: http://www.seer.unirio.br/index.php/cuidadofundamental/article/view/3664
17. Liu L, Liu YP, Wang J, An LW, Jiao JM. Use of a knowledge-attitude-behaviour education programme for Chinese adults undergoing maintenance hemodialysis: Randomized controlled trial. J Int Med Res. 2016 Jun;44(3): 557568. doi: https://doi.org/10.1177/0300060515604980

\section{Acknowledgments:}

To the CNPq for Denise Maria Guerreiro Vieira da Silva's Productivity Scholarship. To CAPES for Julia Estela Willrich Böell's Post-Doctoral Scholarship.

\section{- Corresponding author:}

Mariela Beatriz Andrade Santana

E-mail: mariela.andrade1@gmail.com

\section{Associate editor:}

Graziella Badin Aliti

Editor-in-chief:

Approved: 03.06.2020 